Antonio Scarpa, MD, PhD

Director

Center for Scientific Review

David A. Schwartz, MD

Director, National Institute of

Environmental Health Sciences

Paul A. Sieving, MD, PhD

Director,

National Eye Institute
Stephen E. Straus, MD

Director, National Center for

Complementary and Alternative Medicine

Lawrence A. Tabak, DDS, PhD

Director, National Institute

of Dental and Craniofacial Research

Nora D. Volkow, MD

Director, National Institute

on Drug Abuse
Address correspondence to: Janet S. Austin, austinj@mail.nih.gov.

J. Clin. Invest. 116:1462-1463 (2006). doi:10.1172/JCI28894.

1. Marks, A.R. 2006. Rescuing the NIH before it is too late. J. Clin. Invest. 116:844. doi:10.1172/ JCI28364.

\title{
Planning science (a generation after Lewis Thomas)
}

\begin{abstract}
Andrew Marks' recent editorial eloquently reiterated a concern that many of us have voiced before, that the current policies and practices of the NIH are not serving the public well.
\end{abstract}

In no aspect of public life is the subversion of original science to bureaucratic need more evident than in the recent effort of the NIH, including its present director and the cadre he has enlisted, to centralize the direction of biomedical research. By means of extravagant Roadmaps or Translational Research Centers, they are crippling what has been the most successful research mechanism devised in the United States: the R01.

But in keeping with the custom of their band, the central planners are marching to music written a generation ago. In 1974, Lewis Thomas already complained that "It is administratively fashionable in Washington to attribute the delay of applied science in medicine to a lack of planning ... Do we need a new system of research management, with all the targets in clear display, arranged to be aimed at?” (1).

Thomas also presented an alternative to the best-laid plans of NIH mice and men, to the notion that protocols from above can direct our science. Lewis Thomas again said, "What [research] needs is for the air to be made right. If you want a bee to make honey, you do not issue protocols on solar navigation or carbohydrate chemistry, you put him together with other bees ... and you do what you can to arrange the general environment around the hive. If the air is right, the science will come in its own season, like pure honey" (1).
The R01s made the air right, and working scientists today are far more likely to support the editor of the JCI in his effort to protect them (2) than they are ready to support the shock and awe of NIH planning.

\section{Gerald Weissmann, MD \\ Editor in Chief, \\ The FASEB Journal}

Address correspondence to: Gerald Weissmann,weissg01@endeavor.med.nyu.edu.

J. Clin. Invest. 116:1463 (2006). doi:10.1172/ JCI28895.

1. Thomas, L. 1974. The lives of a cell: notes of a biology watcher. Viking Press. New York, New York, USA. 153 pp.

2. Marks, A.R. 2006. Rescuing the NIH before it is too late. J. Clin. Invest. 116:844. doi:10.1172/ JCI28364.

\section{Response to: "Rescuing the $\mathrm{NIH}$ before it is too late" from the Deputy Director for Extramural Research}

For a number of reasons, the NIH and the biomedical research community are facing a period of fiscal constraint after pronounced growth. In these difficult times, it is important that we all speak from the facts and work together to do a better job of explaining the importance of the nation's investment in biomedical research.

I would like to take this opportunity to respond to the recent editorial (1) raising concerns about the current and future the NIH budget picture and how the NIH manages during a time of fiscal constraint. I agree that there are reasons for serious concern in the scientific com- munity. Adjusting to the new budget realities is difficult, especially after a pronounced period of growth. For this reason, it is important that NIH leadership, grantees, and grantee institutions engage in an open dialogue about managing during tough times. We must, however, speak from the facts - not misinformation, rumor, or speculation.

Clearly, there is great concern about the dropping success rates. In this regard, I would first point out that the drop in success rates is not due to a major shift in the balance of our investments. We continue to support basic research at relatively the same level as in the past - the percentage of basic and applied science funding at NIH was at $55 \%$ and $41 \%$ of the NIH budget, respectively, in 2005, as compared to $54 \%$ and $41 \%$ in 1998 . The drop 